\title{
Antihyperlipidemic and Biochemical Activities of Mcy Protein in Streptozotocin Induced Diabetic Rats
}

\author{
Saritha Marella ${ }^{a}$ Dilip Rajasekhar Maddirela ${ }^{a}$ Kameswara Rao Badrib \\ Malaka Venkateshwarulu Jyothi Kumarc Apparao Chippada ${ }^{a}$ \\ aDepartment of Biochemistry, Sri Venkateswara University, Tirupati, AP, India, ${ }^{b}$ Department of Biology, \\ Savannah State University, Savannah, GA, U.S.A, 'Department of Biotechnology, Sri Venkateswara \\ University, Tirupati, AP, India
}

\section{Key Words}

Antihyperlipidemic - Atherosclerosis - Diabetes mellitus - Streptozotocin - Mcy protein • Momordica cymbalaria

\begin{abstract}
Background: This study was aimed to evaluate the protective effects of a novel antihyperglycemic "Mcy protein" isolated from the fruits of Momordica cymbalaria in streptozotocin induced- diabetes rat model. Materials and Methods: Wild type and Streptozotocin induced diabetic male wistar albino rats were either treated with single intraperitoneal injection of 2.5 $\mathrm{mg}$ Mcy protein/kg body weight or acetate buffer daily for 30 days. Fasting blood glucose and, serum and tissue lipid levels were measured along with biochemical analysis for hepatic and renal function tests. Results: Mcy protein significantly reduced the fasting blood glucose and, serum as well as tissue lipid levels $(p<0.05)$, besides normalizing the levels of liver and kidney function markers in the treated diabetic rats when compared to the diabetic controls. Our studies also showed the pancreatic islet regeneration in Mcy treated rats. Conclusion: Mcy protein can alleviate hyperlipidemia and help manage diabetes by stimulating insulin secretion without evident toxic effects on liver and kidney.
\end{abstract}

Copyright (C) 2015 S. Karger AG, Basel

\section{Introduction}

Diabetes mellitus (DM) is characterized by hyperglycemia causing many complications such as hyperlipidemia, atherosclerosis and other cardiovascular diseases [1]. The most common lipid abnormalities in DM are hypertriglyceridemia and hypercholesterolemia [2]. Hypertriglyceridemia contributes significantly for insulin resistance and glucose intolerance

Dr. Appa Rao Chippada,

and Dr. Kameswara Rao Badri

KARGER 125
Department of Biochemistry, Sri Venkateswara University, Tirupati (India)

and Box 20600, 3219 College Street, Department of Biology, Savannah State University, Savannah 31406, GA, (USA)

E-Mail chippadar@yahoo.com,E-Mail badrik@savannahstate.edu 
[3]. An excess of LDL (low density lipoprotein) cholesterol also causes atherosclerosis, narrowing of coronary artery due to plaque buildup on artery walls and blood clots, further blocking the blood supply to myocardium (heart attack). Cardiac arrest may also result from coronary artery disease (CAD). Ninety percent of sudden deaths occur in patients with two or more major arteries narrowed by atherosclerosis [4]. Abnormal lipid and lipoprotein levels lead to the development of CAD in diabetic patients [5]. Several studies have shown the benefits of lowering lipid levels to satisfactory levels to prevent diabetic complications $[6,7]$.

In spite of the available modern antilipidemic drugs like fibrates and statins, there is a continuous search for new drugs due to the side effects associated with these drugs. In recent years, natural products have gained popularity as therapeutic agents in treating many diseases including DM and associated dyslipidemia because of the minimal to no side effects. Accumulating studies suggest that plant derived products were known to possess anti-diabetic and antihyperlipidemic activities [8]. In this study, an attempt was made to identify the anti-hyperlipidemic activity of Mcy protein that was isolated from the fruits of Momordica cymbalaria and its effect on liver and kidney.

\section{Materials and Methods}

\section{Plant material}

Fruits of M. cymbalaria were collected $[9,10]$ and Mcy protein was purified from the aqueous extract of fruits of M. cymbalaria as previously described [10]. In the current study Mcy protein was used at a dose of $2.5 \mathrm{mg} / \mathrm{kg}$ b.w. as standardized earlier [10].

\section{Experimental design}

Male Wistar Albino rats aged 2-3 months and weighing 180-200 gm were used for the study. The animals were maintained in standard animal house conditions with ad libitum access to food and water under a 12-hour light dark cycle prior to treatment. DM was induced in overnight fasted rats by single intravenous injection of freshly prepared ice cold Streptozotocin (STZ) $(50 \mathrm{mg} / \mathrm{kg}$ body weight) in citrate buffer ( $\mathrm{pH}$ 4.5)[10]. Diabetes was confirmed by measuring fasting blood glucose concentrations. The rats with blood glucose levels $>250 \mathrm{mg} / \mathrm{dl}$ were considered as diabetic and used for the experiment. The study was approved by the Institutional Animal Ethical Committee (Resolution No. 44/2012-2013/(i)/a/ CPCSEA/IAEC/SVU/CAR-MST /dt.08.07.2012).The animals were divided into 5 groups of 6 each. Group1: normal untreated (N), Group2: normal treated with $2.5 \mathrm{mg}$ Mcy protein /kg b.w /day (NT), Group3: diabetic control (DC), Group 4: Diabetic treated with 2.5mg Mcy protein/kg b.w /day (DT) and Group 5: diabetic treated with20mg glibenclamide/kg b.w /day (DGT).

Fasting blood was collected to determine glucose levels every week starting on day one before treatment. The rats of groups 2 and 4 were given Mcy protein through intraperitoneal injection for a period of 4 weeks while groups 1 and 3 were injected with acetate buffer alone. Group 5 rats were given glibenclamide, an oral hypoglycemic agent, as a control. The blood glucose levels and body weights were checked in all groups for 4 weeks. Fasting blood glucose levels were measured using glucose-oxidaseperoxide reactive strips (Accu-chek, Roche Diagnostics, GmbH, Germany) [11]. All the rats were sacrificed on the last day ( $30^{\text {th }}$ day) of treatment by asphyxiation followed by cervical dislocation and the blood (with or without anticoagulant) and tissues were collected for various biochemical estimations. The blood was centrifuged at 7000 rpm for 15 minutes and plasma and serum were collected. For biochemical studies, tissues were frozen and stored at $-80^{\circ} \mathrm{C}$ until used. For histology studies, tissues were immediately fixed in formalin as described below.

\section{Histology}

Histology of the pancreas and liver tissues were performed following standard methods [12]. The pancreas and liver tissues were excised and fixed in $10 \%$ buffered formalin and used to prepare paraffin blocks. Five-micrometer thick sections were cut with microtome and the tissue sections were stained with hematoxylin and eosin. 


\section{Biochemical analysis}

All the analyses were done using Prans Asia semi-automated analyzer. Serum cholesterol and HDLcholesterol were estimated by CHOD-POD [13] method. Serum triglycerides levels were estimated by the method of GPO-POD [14]. The activities of serum glutamic oxaloacetic transaminase (SGOT) and serum glutamic pyruvic transaminase (SGPT) were measured by IFCC/UV-kinetic method [15]. Serum creatinine, total Bilirubin and blood urea were measured by Jaffe's method [16], modified Jendrassik-Grof's method [17] and Ned-dye method [18] respectively. LDL-cholesterol and VLDL-cholesterol were calculated by using Friedwald formula [19]. Glycated hemoglobin $\left(\mathrm{HbA}_{1 \mathrm{c}}\right)$ was measured following the method of Eross et al. [20]. Insulin levels were measured by modified method of Herbert et al [21] using insulin radioimmunoassay kit obtained from BARC, Mumbai, India.

Atherogenic index was calculated using the formula given below.

Atherogenic index $=$ Total cholesterol - HDL-cholesterol/HDL-cholesterol [22].

Oral glucose tolerance test

Another batch of rats were treated in the same way as described above. At the end of the treatment, rats were used for oral glucose tolerance test after overnight fasting. Following 30 minutes of post extract and drug administration, all the animals were orally fed with $2 \mathrm{~g}$ glucose (solution)/kg b.w. with forcefeeding gavage. Blood samples were collected from tail vein prior to the treatment $(0 \mathrm{~min})$ and then at 30 , $60,90,120$, and 150 minutes after glucose administration. The blood glucose levels were measured using glucose-oxidase-peroxidase reactive strips (Accu-chek, Roche Diagnostics, GmbH, Germany).

\section{Statistical analysis}

The data for various biochemical parameters were analyzed using Analysis of Variance (ANOVA) and the significance was calculated using student's t-test. All the results were expressed as mean \pm SEM and the group means were compared by Duncan's multiple range test (DMRT) using SPSS 11.5 computer software.

\section{Results}

To study the effect of Mcy protein on glycemic control, we measured the fasting blood glucose levels, glycated hemoglobin, oral glucose tolerance and plasma insulin levels. Figure 1 shows the beneficial effect of Mcy protein on fasting blood glucose (Fig. 1A), glycated hemoglobin (Fig. 1B), oral glucose tolerance (Fig. 1C) and plasma insulin levels (Fig. 1D). It is evident that Mcy protein is a potent anti-hyperglycemic agent and decreased the glucose levels in diabetic treated group from $300 \mathrm{mg} / \mathrm{dl}$ to $96.5 \mathrm{mg} / \mathrm{dl}$ after 4 weeks of treatment. Diabetic group displayed higher levels of $\mathrm{HbA}_{1 \mathrm{c}}$ compared to normal group (13 $\pm 0.72 \%$ vs. $\left.7.53 \pm 0.95\right)$. Where as with Mcy protein treatment, $\mathrm{HbA}_{1 \mathrm{c}}$ levels were reduced to near normal(7.6 $\left.\pm 0.8 \%\right)$. We further verified whether the treatment improves oral glucose tolerance with Mcy treatment and Mcy protein treated animals showed significant improvement in oral glucose tolerance (69\% fall in blood glucose at $150 \mathrm{~min}$, Fig. 1C). The anti diabetic effect (indicated by $\mathrm{HbA}_{1 \mathrm{c}}$ and blood glucose) of Mcy protein was much better than that of glibenclamide. In addition, we verified the plasma insulin levels and observed a significant decrease in plasma insulin levels (Fig. 1D) of diabetic untreated rats when compared to normal rats. However, the Mcy treatment in diabetic rats increased the insulin levels to a normal range (from $8.7 \pm 0.05 \mu \mathrm{U} / \mathrm{ml}$ to $12.9 \pm 0.05 \mu \mathrm{U} / \mathrm{ml}$ ). As expected glibenclamide treated group also showed significant increase in plasma insulin levels.

To study the therapeutic effects of Mcy protein on hyperglycemia induced dyslipidemia we measured the lipid levels in various tissues including serum. Figure 2 shows the beneficial effect of Mcy protein on lipid levels of serum (Fig. 2A), kidney (Fig. 2B), liver (Fig. 2C) and skeletal muscle (Fig. 2D) of experimental animals. Diabetic untreated rats showed increased levels of serum and tissue triglycerides, total cholesterol, LDL-cholesterol and VLDL cholesterol. However, Mcy protein significantly reduced the serum triglycerides (from $87 \mathrm{mg} / \mathrm{dl}$ to $64 \mathrm{mg} / \mathrm{dl}$ ), total cholesterol (from $126 \mathrm{mg} / \mathrm{dl}$ to $101.6 \mathrm{mg} / \mathrm{dl}$ ), LDL-cholesterol (from $37.23 \mathrm{mg} / \mathrm{dl}$ to $29 \mathrm{mg} / \mathrm{dl}$ ) and VLDL-cholesterol (from $26 \mathrm{mg} / \mathrm{dl}$ to $12.7 \mathrm{mg} / \mathrm{dl}$ ) $(\mathrm{p}<0.05)$ levels to near normal. Additionally, HDL-cholesterol, good cholesterol levels were 


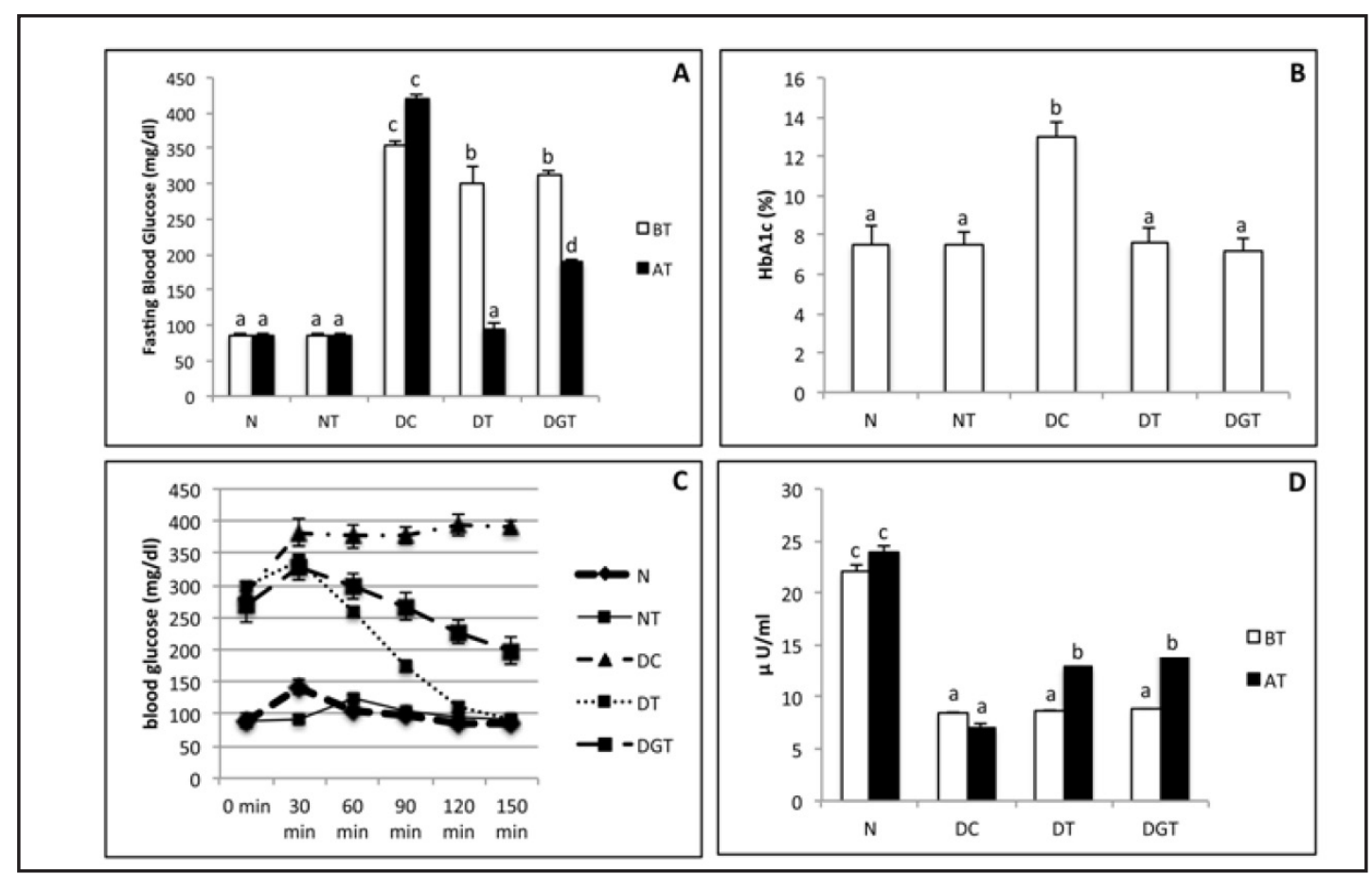

Fig. 1. Effect of Mcy protein on fasting blood glucose level (A), glycosylated hemoglobin (HbA1c, B), glucose tolerance (C) and plasma insulin levels (D). N-normal rats; NT-normal rats treated with Mcy protein; DCdiabetic rats, DT-diabetic rats treated with Mcy protein; DGT-diabetic rats treated with glibenclamide.BT - Before Treatment.AT - After Treatement.Values not sharing a common superscript differ significantly at $\mathrm{p}$ $\leq 0.05$. Duncan's Multiple Range Test (DMRT). Values are represented as Mean \pm SEM. $n=6$ rats in each group.

significantly increased in the Mcy treated rats (from $24.66 \mathrm{mg} / \mathrm{dl}$ to $43 \mathrm{mg} / \mathrm{dl}$ ) after the treatment (Fig. 2A). Similar results were also observed in the lipid levels of the other tissues tested, kidney (Fig. 2B), liver (Fig. 2C) and skeletal muscle (Fig. 2D). Furthermore, Table 1 shows the atherogenic index for the normal and diabetic rats with or without Mcy treatment. The atherogenic index for diabetic control rats is significantly higher than that in the normal rats. Conversely, Mcy protein treatment significantly reduced the atherogenic index to near normal.

To study the protective effects of Mcy protein on liver and kidney, we assayed serum glutamic oxaloacetic transaminase (SGOT) and serum glutamic pyruvic transaminase (SGPT) enzymes. We further measured blood urea, creatinine and total bilirubin levels. Fig. 3 shows the activities of hepatic function marker enzymes (SGOT and SGPT, Fig. 3A) and concentrations of metabolites (urea, creatinine and total bilirubin, Fig. 3B-D) the markers of renal and hepatic functions. The activities of SGOT and SGPT were significantly decreased to near normal (from $41.5 \mathrm{IU} / \mathrm{L}$ to $35.3 \mathrm{IU} / \mathrm{L}$ and from $43.16 \mathrm{IU} / \mathrm{L}$ to $36 \mathrm{IU} / \mathrm{L}$ respectively) after the treatment with Mcy. Mcy protein also reduced the levels of creatinine (from $2.1 \mathrm{mg} / \mathrm{dl}$ to $0.9 \mathrm{mg} / \mathrm{dl}$ ), bilirubin (from $1.7 \mathrm{mg} / \mathrm{dl}$ to $1.1 \mathrm{mg} / \mathrm{dl}$ ) and urea (from $75.3 \mathrm{mg} / \mathrm{dl}$ to $64 \mathrm{mg} /$ dl) in diabetic treated rats to near normal values [Fig. 3]. Glibenclamide treated diabetic rats also showed significant decrease in the activities of SGOT, SGPT and levels of urea, creatinine and total bilirubin.

Figure 4 shows the histology of pancreas of normal (A), normal treated (B), diabetic control (C) and diabetic rats treated with Mcy protein (D). Control rats showed a normal lobular architecture of the pancreas with abundant islets of langerhans interspersed among the pancreatic exocrine acini. The islets appeared lightly stained than the surrounding acinar cells, with intact interlobular connective tissue and interlobular duct. The pancreatic sections of the diabetic group showed marked morphological changes and revealed changes in microanatomical features like congestion and $\beta$ cell degranulation of the islets. Destruction of islet 


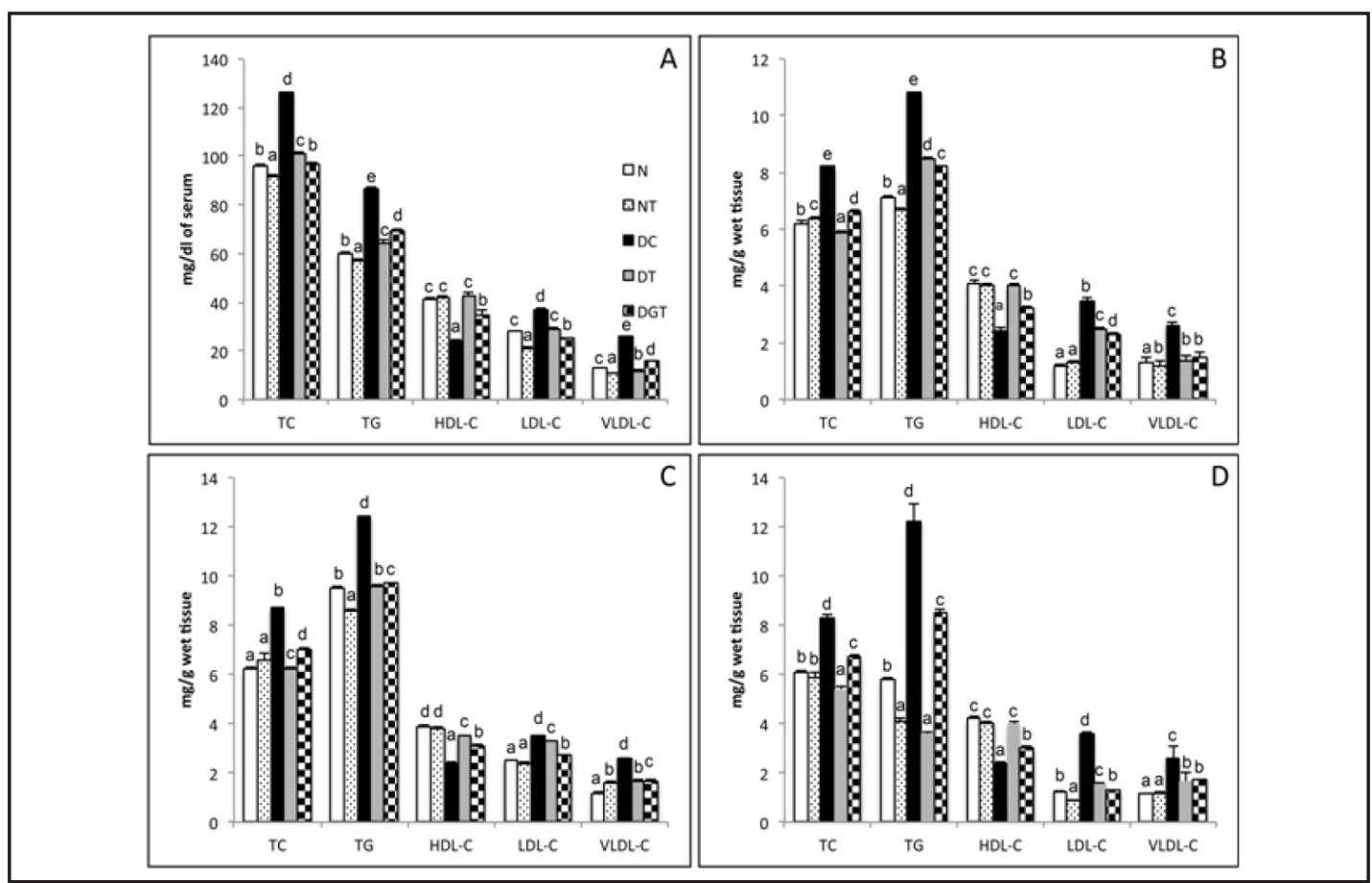

Fig. 2.Effect of Mcy on lipid profile in serum (A), kidney (B), liver (C) and skeletal muscle (D). N-normal rats; NT-normal rats treated with Mcy protein; DC-diabetic rats, DT-diabetic rats treated with Mcy protein; DGT-diabetic rats treated with glibenclamide.TC-total cholesterol; TG-triglycerides; HDL-C-high density lipoprotein cholesterol; LDL-C-low density lipoprotein cholesterol; VLDL-C-very low density lipoprotein cholesterol. Values not sharing a common superscript differ significantly at $\mathrm{p} \leq 0.05$. Duncan's Multiple Range Test (DMRT). Values are represented as Mean \pm SEM. $n=6$ rats in each group.

Table 1. Effect of Mcy on Atherogenic index. N-normal rats; NT-normal rats treated with Mcy protein; DC-diabetic rats, DT-diabetic rats treated with Mcy protein; DGT-diabetic rats treated with glibenclamide

\begin{tabular}{lccccc}
\hline Group & $\mathrm{N}$ & $\mathrm{NT}$ & $\mathrm{DC}$ & $\mathrm{DT}$ & DGT \\
& & & & & \\
\hline Atherogenic Index (units) & $1.24 \pm 0.003^{\mathrm{a}}$ & $1.27 \pm 0.003^{\mathrm{a}}$ & $4.18 \pm 0.04^{\mathrm{c}}$ & $1.34 \pm 0.003^{\mathrm{b}}$ & $1.38 \pm 0.005^{\mathrm{b}}$ \\
& & & & & \\
\hline
\end{tabular}

cells in diabetic rats was prominent as they are irregularly shaped and atrophic. The partial restoration of the pancreatic islets cells was observed after treatment with the Mcy protein. The liver sections show well arranged cells and a clear central vein with discoloration/pale color in diabetic untreated group (Data not shown). We did not observe any significant changes in the histology of livers of various groups of rats.

\section{Discussion}

DM characterized by hyperlipidemia may be due to the impaired actions of lipolytic hormones on the fat depots. Diabetic complications can be prevented by administration of traditional therapeutic principles [23]. Administration of Mcy protein normalized the levels of glucose, lipids, bilirubin, urea and creatinine in diabetic rats. Elevation of serum lipids in DM represents a risk factor for coronary heart disease [24]. The abnormally high concentration of lipids in serum is mainly due to increase in the mobility of free fatty acids from peripheral depots [25]. It is evident from the literature that many herbal products isolated from plant KARGER 


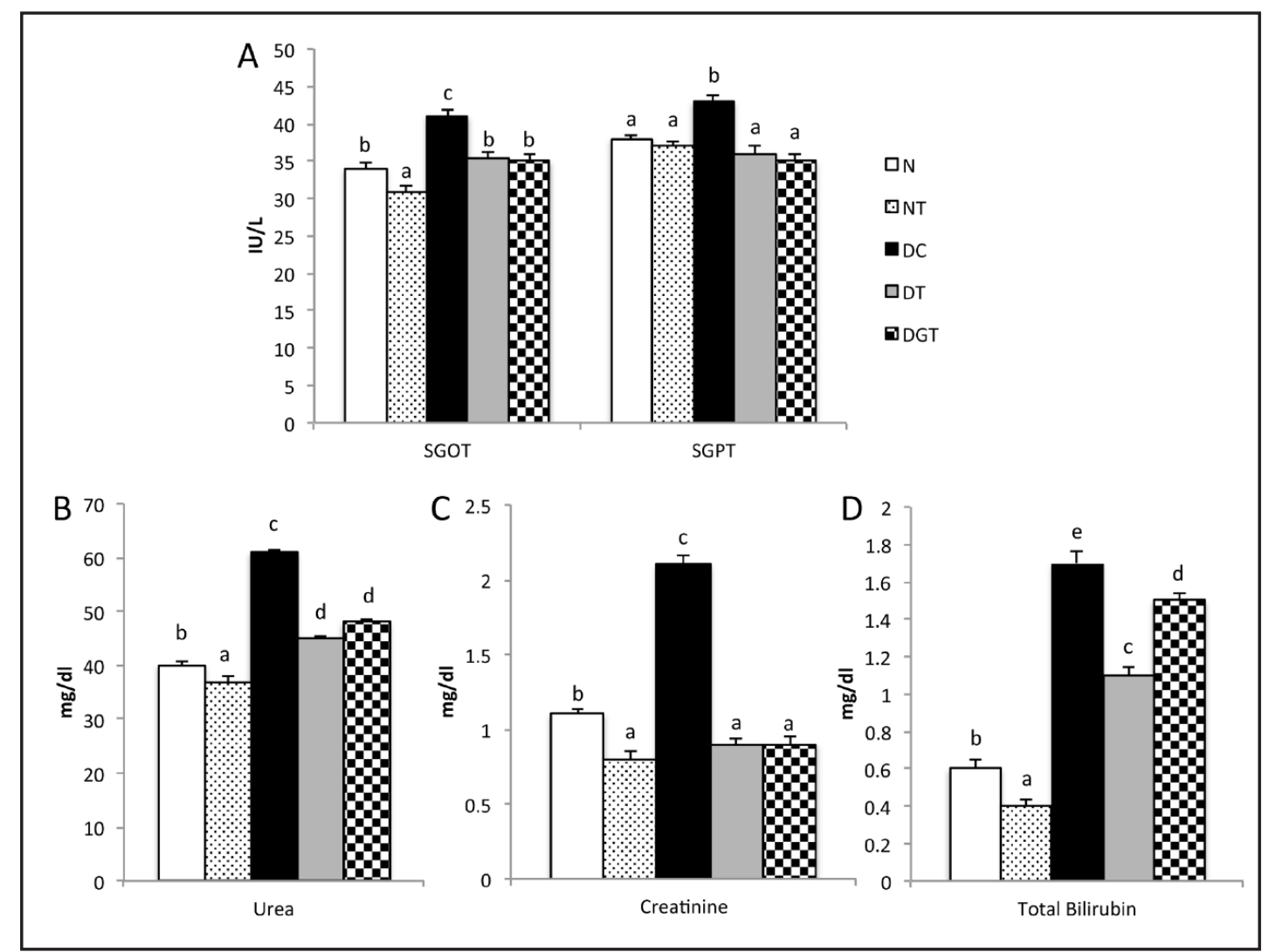

Fig. 3. Effect of Mcy on SGOT, SGPT (A), Urea (B), Creatinine (C) and Total Bilirubin (D). N-normal rats; NT-normal rats treated with Mcy protein; DC-diabetic rats, DT-diabetic rats treated with Mcy protein; DGTdiabetic rats treated with glibenclamide. SGOT-serum glutamic oxaloacetic transaminase; SGPT-serum glutamic pyruvic transaminase. Values not sharing a common superscript differ significantly at $\mathrm{p} \leq 0.05$. Duncan's Multiple Range Test (DMRT). Values are represented as Mean \pm SEM. $n=6$ rats in each group.

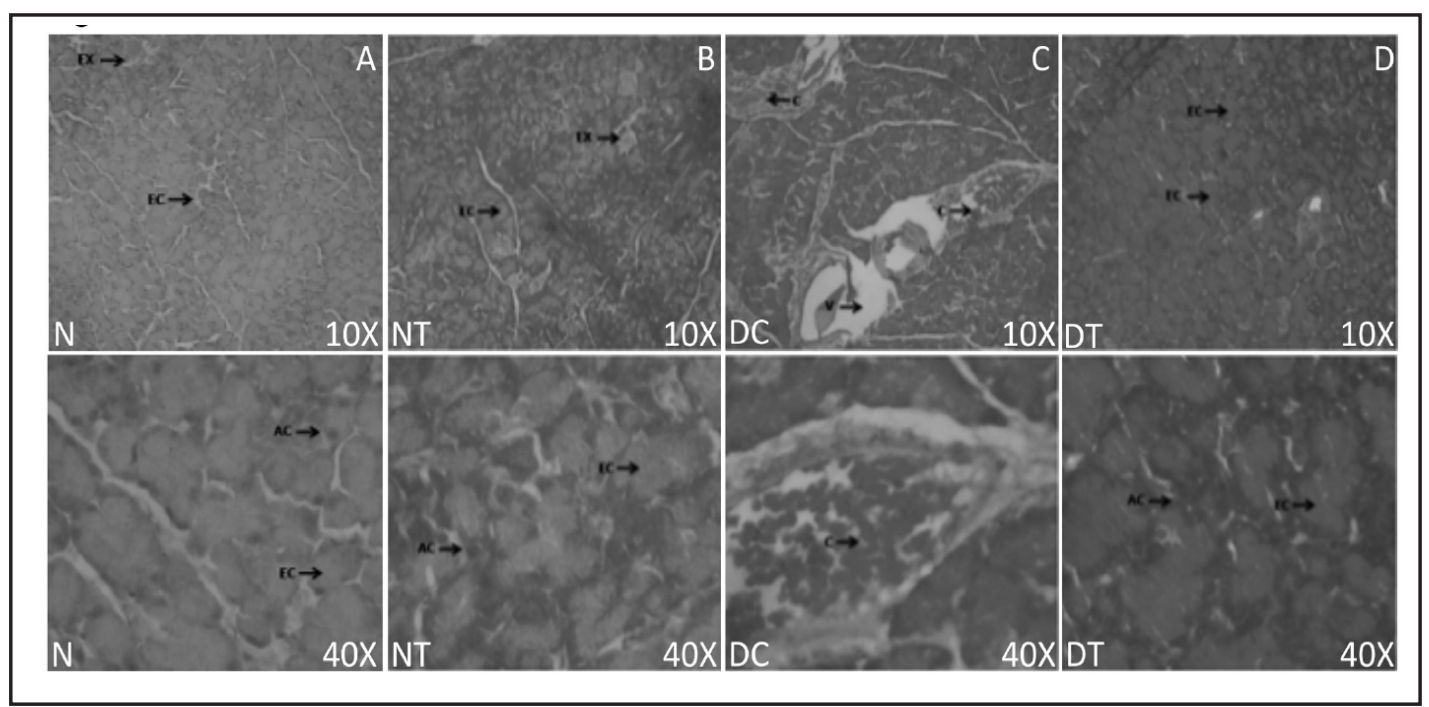

Fig. 4. Effect of Mcy protein on the histology of pancreas. N-normal rats (A); NT-normal rats treated with Mcy protein (B); DC-diabetic rats (C), DT-diabetic rats treated with Mcy protein (D). H\&E staining. 10X and 40X magnifications.EX - exocrine part, EN - endocrine part, AC - acinar cells, $\mathrm{C}$ - congestion. 
source serve as good anti-hyperlipidemic agents. For the treatment of various diseases active principles were isolated from natural sources that paved the way for the synthesis of various drugs including metformin [26]. The fruit extract of Momordica charantia was proved to have excellent anti-hyperglycemic and anti-hyperlipidemic activities [27]. In the present study the results show that Mcy protein has significant anti-hyperlipidemic activity by reducing the levels of triglycerides, total cholesterol, LDL cholesterol and VLDL cholesterols in serum as well as in major target tissues.

Some of the major anti-hyperlipidemic mechanisms include; 1 . Inhibition or reduction of cholesterol biosynthesis especially by lowering the 3-hydroxy-3-methyl glutaryl coenzyme A reductase (HMG Co A reductase) activity, a key enzyme of cholesterol biosynthesis [28], 2. reduced triglyceridemic due to decrease in fatty acid synthesis [29], enhanced catabolism of LDL-C, activation of lecithin-cholesterol acyl transferase and tissue lipases [30], inhibition of acetyl CoA carboxylase[31] and production of triglyceride precursors such as acetyl CoA and glycerol phosphate. Hyperglycemia and the vascular complications of diabetes correlated with increased non-enzymatic and auto-oxidative glycosylation [6, 7]. While we investigate these mechanisms, one important factor, which contributed for the effect of Mcy protein on lipid metabolism, could be the good glycemic control in diabetic treated rats. Decreased levels of HbA1c and improved glucose tolerance in diabetic group treated with Mcy protein clearly indicate the tight glycemic control in these animals. Mcy protein treatement showed significant anti-hyperlipidemic effect in normalizing serum, hepatic and renal tissue lipids. Mcy protein is equally effective as glybenclamide, however, the antihyperlipidemic effect of Mcy protein in skeletal muscle tissue is very significant and better than glibenclamide indicating additional mechanisms of function.

SGOT and SGPT are hepatic enzymes and biomarkers for abnormal liver funtion or hepatic injury [32]. Elevated SGOT and/or SGPT levels may also be considered as predictors of DM [33]. Administration of Mcy improved the liver function by decreasing the activities of SGPT and SGOT $(\mathrm{p}<0.05)$ to normal in diabetic rats. Elevation of SGOT and SGPT will increase the incidence of heart and liver diseases. GOT is found primarily in cells of liver, heart, skeletal muscle, kidney and pancreas. It is released into serum in larger quantities during the tissue damage. Significant rise in serum GOT and GPT activities in diabetic rats could be due to excess protein catabolism with accumulation of aminoacids like glutamate and alanine in the serum of diabetic animals [34]. Mcy protein decreased SGOT activity indicating the protective effect on liver and possibly also on heart as indicated by reduced levels in Mcy treated group. The levels of serum enzymes change in accordance with change in the metabolism in which they are involved. Hence, the improvement in the activities of SGOT and SGPT may be due to improvement in the carbohydrate, fat and protein metabolism on treatment with Mcy protein.

Elevated blood urea and creatinine levels are markers for impaired kidney function in diabetic nephropathy, which were observed in STZ induced diabetic rats [35]. Elevated urea levels in diabetic rats are associated with increased protein breakdown. Positive correlation was seen between hyperglycemia and nephropathy [36]. Treatment of diabetic rats with Mcy reduced the levels of urea and creatinine near to normal. Elevated bilirubin levels indicate enormous destruction of hemoglobin or may be malfunctioning of liver in hemoglobin metabolism [37]. Administration of Mcy normalized the levels of bilirubin. Mcy protein might be eliciting this protective effect directly on the targeted tissues. Another possibility is that it could be due to insulin mimetic activity, pancreatic $\beta$ cell stimulatory or regenerative function of Mcy protein.

To identify the mechanisms underlying Mcy induced anti-hyperglycemia and antihyperlipedmia, we investigated the effect of Mcy protein on insulin secretion and histology of pancreas. Our studies showed that insulin secretion was significantly elevated in diabetic rats treated with Mcy protein. Further histology studies confirmed that this is due to regeneration of the pancreatic $\beta$ cells. Increased weights of rats with the treatment of Mcy protein also confirms the elevated insulin levels in Mcy treated diabetic group. However, stimulation of remnant pancreatic $\beta$ cells by Mcy protein and insulin mimicking activity of Mcy 
protein due to possible structural similarity with insulin [10] cannot be ignored. Previously similar studies using protein extracts from the fruits of Momordica charantia showed insulin secretagogue and insulinomimetic activities in STZ induced diabetic rats [38]. Identification of insulin receptor binding-peptide from Momordica charantia [39] signifies the presence of phytohormones that are capable of regulating insulin signaling pathways.

\section{Conclusion}

The results indicate that besides lowering the blood glucose levels, Mcy protein has potential beneficial effects by decreasing the levels of total cholesterol, triglycerides, LDLcholesterol, VLDL-cholesterol and increasing HDL-cholesterol. The hepatic function markers SGOT,SGPT activities and serum bilirubin and the renal function markers such as serum creatinine and urea were also normalized after the treatment with Mcy protein compared to untreated diabetic rats. Therefore, our studies suggest that Mcy protein has potent antihyperlipidemic activity besides anti-hyperglycemic activity and shows protective effect against hepatic and renal damage caused in DM. The study also demonstrates that Mcy protein has a regeneration effect and possibly stimulatory effect on the remnant $\beta$ cells and thus increasing insulin secretion.

\section{Disclosure Statement}

The authors have no conflict of interest to disclose.

\section{References}

1 Alberti KGMM, Zimmet P, Defronzo RA: International textbook of Diabetes mellitus (2nd Ed). John Wiley and Sons, New York 1997.

2 Khan BA, Abraham A, Leelamma S: Hypoglycemic action of Murraya koenigii (curry leaf), Brassica juncea (mustard) mechanism of action. Ind J Biochem Biophys 1995;32:106-108.

3 Gingsberg HN: Lipoprotein metabolism and its relationship to atherosclerosis. Med Clin North Am 1994;78:1-20.

4 Web Med Health-online Web health bulletin-heart disease risk factors for CAD \& CAD overview sep-2004.

5 Sarti C, Gallagher J: The metabolic syndrome: Prevalence, CHD risk and treatment. Diabetes Complications 2006;20:121-132.

6 Kesavulu MM, Kameswara Rao B, Giri R, Apparao Ch: Lipid peroxidation and antioxidant enzyme status in type 2 diabetics with coronary heart disease. Diabetes Res Clin Pract 2001;53: 41-47.

7 Kesavulu MM, Giri R, Kameswara Rao B, Apparao Ch: Lipid peroxidation and antioxidant enzyme levels in type 2 diabetics with micro vascular complications. Diabetes Metabol2000;26:387-392.

8 Elder C: Ayurveda for diabetes mellitus: A review of the biomedical literature. Altern Ther Health Med 2004;10:44-50.

9 Rao BK, Kesavulu MM, Apparao Ch: Antihyperglycemic activity of Momordica cymbalaria in alloxan diabetic rats.J Ethnopharmacol 2001;78:67-71.

10 Rajasekhar MD, Badri KR, Kumar VK, Babu KR, Fatima SS, Sampath Kumar MT, Apparao C: Isolation and characterization of a novel antihyperglycemic protein from the fruits of Momordica cymabalaria. J Ethnopharmacol 2010;128:58-62.

11 Ramdas RB, Sangameswaran B, Mohite PB, Khanage SG: Antidiabetic activity of aqueous leaves extract of Sesbaniasesban (L) Merr.in streptozotocin induced diabetic rats. Avicenna J Med Biotechnol 2011;3:43.

12 Badri KR, GaoL, Hyjek E, Schuger N, Schuger L, Qin W, Chekaluk Y, Kwiatkowski D, Zhe X: Exonic mutations of TSC2/TSC1 are common but not seen in all sporadic pulmonary Lymphagioleiomyomatosis (LAM). Am J Respirat Crit Care Med 2013;187:663-665.

13 Richmond W: Preparation and properties of a cholesterol oxidase from Nocardia sp. and its application to the enzymatic assay of total cholesterol in serum. Clin Chem1973;19:1350-1356. 


\begin{tabular}{|c|c|c|}
\hline Cellular Physiology & Cell Physiol Biochem 2015;35:1326-1334 & \\
\hline and Biochemistry & $\begin{array}{l}\text { DOI: 10.1159/000373954 } \\
\text { Published online: February 12, } 2015\end{array}$ & $\begin{array}{l}\text { O } 2015 \text { S. Karger AG, Basel } \\
\text { www.karger.com/cpb }\end{array}$ \\
\hline
\end{tabular}

14 Balch PA: Prescription for nutritional healing. 4th ed. New York. Avery, 2006, p. 54, Carnitine.

15 Chernecky CC, Berger BJ (eds): Laboratory Tests and Diagnostic Procedures 4th ed. Philadelphia, Saunders, 2004.

16 Slot C: Plasma Creatinine Determination. A new and specific Jaffe Reaction Method. Scand J Clin Lab Inv 1965;17:381-387.

17 Choosongsang P, Bodhikul A, Musigavon P, Pocathikorn A, Prasongsab T, Musaw A: Modified JendrassikGrof Method for Measurement of Direct Bilirubin. An Improvement of In-House Method. Songkla Med J 2011;29:19-26.

18 Fawcett JK, Scott JE: A rapid and precise method for the determination of Urea. J Clin 1960;13:156-159.

19 Friedwald WT, Levy RI, Fredrickson DS: Estimation of the concentration of LDL-C in plasma without the use of preparative ultracentrifuge. Clin Chem 1972;18:499-502.

20 Eross J, Kreutzmann D, Jimenez M, Keen R, Rogers S, Colwell C, Vines R, Sinik M: Colorimetric measurement of glycosylated protein in whole blood cells plasma and dried blood. Ann Clin Biochem 1984;21:519-522.

21 Herbert V, Lan KS, Gttlies CW, Bleiches SG: Coated charcoal immunoassay of insulin. J Clin Endocrinol Metab 1965;25:1375-1385.

22 Kayamori F, Igarashi K: Effects of dietary nasunin on the serum cholesterol level in rats. Bios Biotech Bioch1994;58:570-571.

23 Packer L, Rosen P, Tritschler H, King GL, Azzi A (eds): Antioxidants and Diabetes Management. New York, Marcel Dekker 2000.

24 Kannel WB, McGee DL: Diabetes and glucose tolerance as risk factors for cardiovascular disease. the Framingham study. Diabetes Care 1979;2:120-126

25 Ahmed I, Lakhani MS, Gillett M, John A, Raza H: Hypotriglyceridemic and hypocholesterolemic effects of antidiabetic Momordica charantia fruit extract in (STZ) induced diabetic rats. Diabetes Res Clin Pract 2001;51:155-161.

26 Cox PA, Balick MJ: The Ethnobotanical Approach to Drug Discovery. Sci Am 1994;270:82-87.

27 Nafisa Fernandes PC, Chakradhar Lagishetty V, Vandana Panda S, Suresh Naik R: An experimental evaluation of the antidiabetic and antilipidemic properties of a standardized Momordica charantia fruit extract. BMC Complement Altern Med 2007;7:29.

28 Kedar P, Chakrabarti CM: Effects of bitter guard (Momordica charantia) seed in Streptozotocin induced diabetes mellitus. Indian J Exp Biol 1982;20:232-235.

29 Bopanna KN, Kannan J, Gadgil S, Balaram R, Rathod SP: Antidiabetic and antihyperlipidemic effects of neem seed kernel powder on alloxan diabetic rabbits. Ind J Pharmacol 1997;29:162-167.

30 Khanna AK, Rizvi F, Chander R: Lipid lowering activity of Phyllanthus niruri in hyperlipidemic rats. J Ethnopharmacol 2002;82:19-22.

31 McCarty M: Inhibition of acetyl CoA carboxylase by cystamine may mediate the hypotriglyceridemic activity of pantethine. Med Hypoth 2001;56:314-317.

32 Semwal BC, Shah K, Chanuhan NS, Badhe R, Divakar K: Antidiabetic activity of stem bark of Berberis aristata D.C in alloxan induced diabetic rats. Int J Pharmacol 2008;6:224 230.

33 Harris EH: Elevated liver function tests in type 2 diabetes. Clin Diabetes 2005; 23:115-119.

34 Colev V, Badescu M, Paduraru I: The zinc metabolic disorder relation in experimental diabetes mellitus. Rom J Inter Med 1994;32:71-75.

35 Ronco C, Grammaticopoulos S, Rosner M, Decal M,Soni S, Lentini P, Piccinni P: Oliguria: creatinine and other biomarkers of acute kidney injury. Contribut Nephrology 2010;164:118-127.

36 Ceriello A, Morocutti A, Franceschina M, Quagliaro L, Moro M, Damante G, Viberti GC: Defective intracellular Antioxidant Enzyme Production in Type 1 Diabetic Patients with Nephropathy. Am Diabetes Assoc 2000;49:2170-2177.

37 Andullu B, Vardacharyulu NCH: Effect of mulberry leaves on diabetes. Int J Diab Dev Ctries 2001;21:147151.

38 Yibchok-anun S, Adisakwaltana S, Yao CY, Sangvanich P, Roengsumran S, Hsu WH: Slow acting protein extract from fruit pulp of Momordica charantia with insulin secretagogue and insulinomimetic activities. Biol Pharma Bull 2006;29:1126-1131.

39 Hsin-YiLo, Tin-Yun Ho, Chingju Lin, Chia-Cheng Li, Chien-Yun Hsiang: Momordica charantia and its novel polypeptide regulate glucose homeostasis in mice via binding to insulin receptor. J Agric Food Chem 2013;61:2461-2468. 